\title{
Understanding patterns of tree adoption on farms in semi- arid and sub-humid Ethiopia
}

\author{
Miyuki Iiyama - Abayneh Derero - Kaleb Kelemu • Catherine Muthuri • \\ Ruth Kinuthia · Ermias Ayenkulu • Evelyn Kiptot • Kiros Hadgu • \\ Jeremias Mowo $\cdot$ Fergus L. Sinclair
}

Received: 9 March 2015 / Accepted: 17 March 2016/Published online: 30 March 2016

(C) The Author(s) 2016. This article is published with open access at Springerlink.com

\begin{abstract}
Trees on farms are a widespread feature of landscapes across a large part of Ethiopia with an important role in enhancing the resilience of smallholder livelihoods through the provision of ecosystem services. Despite their importance, little is known about what trees are planted or retained from natural regeneration by different types of farmers that results in the pattern of tree cover found in the region. We address this knowledge gap through analysis of household survey data from semi-arid and sub humid areas of Oromia regional state. A set of composite variables that represent distinctive patterns of tree cover on farms were derived from principal component
\end{abstract}

M. Iiyama $(\varangle) \cdot$ C. Muthuri · R. Kinuthia .

E. Ayenkulu - E. Kiptot - K. Hadgu · J. Mowo .

F. L. Sinclair

World Agroforestry Centre (ICRAF), Nairobi, Kenya

e-mail:m.iiyama@cgiar.org

M. Iiyama

Japan International Research Center For Agricultural

Sciences (JIRCAS), Tsukuba, Japan

A. Derero

Ethiopian Environment and Forest Research Institute,

Addis Ababa, Ethiopia

K. Kelemu

Ethiopian Institute of Agricultural Research,

Addis Ababa, Ethiopia

F. L. Sinclair

Bangor University, Wales, UK analysis and Pearson correlation analysis. This revealed two major tree adoption strategies: farmer managed natural regeneration (FMNR) of trees to meet subsistence needs as well as contributing to other ecosystem services; and, high value agroforestry (HVAF) involving planted trees used largely to produce fruits, timber and fodder. Regression analysis further identified fine-scale variation in ecological and socio-economic factors that affect which of these two broad strategies are adopted by farmers. Favorable climatic conditions coupled with institutional arrangements to control free grazing were pre-conditions for HVAF, whereas poor biophysical potential and sloping land provided a positive incentive for farmers to adopt FMNR. Farmers with preferences for tree species with multiple utilities and locational flexibility favored FMNR while adoption of HVAF was more assetdriven. Our findings reveal that farmers integrate many native and exotic tree species on their farms to meet their variable farm conditions, needs and asset profiles in stark contrast to most tree promotion efforts that focus on a few, usually exotic, tree species. We recommend that future agroforestry promotion should embrace a diversity of tree species appropriate to matching the fine scale variation in ecological conditions and farmer circumstances encountered in the field.

Keywords Characterization - Farmer managed natural regeneration $($ FMNR) $\cdot$ Ecosystem services · Livelihoods 


\section{Introduction}

Ethiopia's economy is heavily dependent on agriculture which supports $83 \%$ of the population mainly through production of rain-fed grain, predominantly teff, maize and wheat as well as livestock, principally cattle, sheep and goats (Deressa et al. 2009). During the last century, the expansion of agriculture to support the growing population was in general achieved by massive deforestation that has been followed by soil degradation (Bewket 2002; Gelaw et al. 2014). Over much of the country this has transformed forests and woodlands into agricultural land with scattered trees (Tesfaye et al. 2014).

Trees on farms are characteristic of a large part of the Ethiopian agricultural landscape today, while tree species distribution and management intensity varying with agro-ecological conditions principally defined by rainfall, altitude, and soil type (Poschen 1986; Teklay et al. 2007; Gelaw et al. 2014). It is common for farmers to manage natural regeneration of trees (FMNR) within crop fields by protecting seedlings and young trees, mostly native species that have germinated from soil seedbanks (Poschen 1986). Farmers usually retain between 1-20 trees of selected species per hectare and minimize impact on the companion crops through occasional lopping and pollarding of trees (Poschen 1986). Examples of this practice include Cordia africana intercropping with maize in sub-humid zones (Yadessa et al. 2009), Faidherbia-based agroforestry in teff-wheat zones (Poschen 1986) and a diverse range of Acacia species such as A. tortilis and A. senegal in fields in low lying savanna regions (Degefu et al. 2011). It is also common for farmers to deliberately plant and manage trees on their farms, such as fast growing timber woodlots predominantly using Eucalyptus spp. or fruit orchards (Deininger and Jin 2006).

Through FMNR and active tree planting on farms, the widespread adoption of trees on agricultural land can play an important role in enhancing tree diversity and cover at landscape scale. This can mitigate and reverse deforestation and land degradation with large potential for soil organic carbon and nitrogen sequestration (Bewket 2002; Mekuria and Aynekulu 2013; Gelaw et al. 2014). The positive relationship between higher rural population and tree cover observed by Tiffen et al. (1994) in semi-arid Kenya has been also reported in the Blue Nile basin as tree cover has been restored over the last four decades as a result of local initiatives to plant trees at the household level along with community afforestation and forest protection (Bewket 2002).

Since the early 1990s there has been a surge of research on the adoption of agroforestry innovations in the tropics, motivated by a perceived gap between advances in agroforestry science and the rate of adoption of trees on farms (Mercer 2004). They can be largely categorized into either ex-ante or ex-post adoption studies. Ex-ante studies rely primarily on social and financial analyses of on-farm trials of agroforestry innovations to assess their adoption potential (Franzel and Scherr 2002). In contrast, ex-post studies aim at identifying factors that have affected adoption through analysis of data on the performance of agroforestry options on farm and the types of farmers who have and who have not adopted (Coe et al. 2016). A meta-analysis of 120 ex-post studies concluded that technology adoption was explained by preferences, resource endowments, market incentives, biophysical factors, and risk and uncertainty (Pattanayak et al. 2003). Meijer et al. (2015) argue that intrinsic factors such as knowledge and attitudes of farmers are also critical. Both ex-ante and ex-post studies recognize the multicomponent nature of agroforestry (Mercer 2004). Most of these studies, however, focus on a single "modern" or "new" agroforestry technology, and methodologically treat the adoption as a binary choice of planting a specific tree species or not, driven by financial and economic factors (Mercer 2004). For example in Ethiopia, several studies examined factors affecting the uptakes of small-scale Eucalyptus woodlots by smallholders (Deininger and Jin 2006; Jagger and Pender 2003). Costs and returns of investment emerged critical in determining decisions to plant trees along with tenure security (Jagger et al. 2005; Duguma 2013).

In contrast, research on adoption has rarely studied indigenous agroforestry systems in the tropics that have evolved uniquely within the locally specific landscape contexts they are embedded in, often over long time periods (Sinclair and Walker 1999). Biggelaar and Gold (1996), based on a case study from Rwanda, argue that the adoption of indigenous agroforestry systems are driven by farmers' preferences for specific tree species with multiple utilities and locational flexibility rather than solely driven by financial and economic factors. Indeed, many farmers 
in Ethiopia, including those who have not practiced any form of intensive tree planting, implement FMNR to manage a set of indigenous species scattered on farm, not only for goods such as fuel, fodder, and fruits, but also for ecosystem services such as shade and soil amelioration (Poschen 1986). A household normally keep indigenous trees across farmlands for multiple utilities that they deem manageable and valuable in order to optimize capture and use of scarce environmental resources (Negash 2007).

In reality, different agroforestry practices such as various forms of tree planning and indigenous practices such as FMNR co-exist (Nyaga et al. 2015). Unfortunately, there have been few empirical studies in Ethiopia or further afield in sub-Saharan Africa (SSA) to understand patterns of tree cover in agricultural landscapes as a whole rather than focusing on a single technology. It is imperative to address this gap both in terms of knowledge and methodology if present landscapes are to be understood and their future resilience ensured.

The objectives of this paper are two-fold. Firstly, to present a novel systematic method for characterizing complex patterns of tree cover on farms, including both indigenous practices and tree planting as a commercial investment in terms of their structure (species composition), function (utilities) and socioeconomic aspects (management intensity and commercial goals). Secondly, to identify a fine scale variation in factors that affects their adoption.

\section{Methods}

We used household survey data from both semi-arid and sub-humid agroecosystems in Ethiopia to characterize tree cover on farms by deriving proxy variables reflecting adoption intensities as well as multi-dimensionality of utilities using a multi-variate analytical method. We then examined associations between distinctive patterns of tree adoption on farms and both ecological and socioeconomic factors that determine their adoption and can be used to match agroforestry interventions to the contexts in which they are appropriate.

Study area, data collection

The Oromia National Regional State accounts for $34 \%$ of the total area of Ethiopia (The National
Regional Government of Oromia 2016) and with a population of over 27 million people (Federal Democratic Republic of Ethiopia Population Census Commission 2008), is the largest state in terms of land area and population in the country. It is a region of great physiographic diversity whose landscapes include high and rugged mountain ranges, undulating plateaus, panoramic gorges, deep incised river valleys and rolling plains (Ethiopian Government Portal, accessed January 7, 2016). The lowlands of the eastern subregion have an arid climate. The intermediate highlands of central and western Oromia have a hot tropical rainy climate, while the highlands have a warm temperate, rainy climate. The distribution of mean annual rainfall varies from place to place and from year to year, decreasing in all directions from the western highlands (1600-2400 mm) towards the eastern and south eastern arid lowlands (less than $400 \mathrm{~mm}$ ) (The National Regional Government of Oromia 2016). The present research was conducted in East Shewa Zone that falls within the semi-arid agroecology, and East Wollega and West Shewa Zones that are in the sub-humid agroecology (Fig. 1).

The semi-arid sites mostly fall in the lowlands of the Central Rift Valley with an altitude less than $1500 \mathrm{~m}$, then rise up to $2300 \mathrm{~m}$ at the mountain fringes of the Rift. Grain crop and livestock farming are dominant in the study area. Some diversity is observed in terms of the combination and management of treecrop systems (Endale 2014); from teff-wheat plus Faidherbia albida (syn. Acacia albida Delile A.Chev, locally called gerbi) to maize-beans-sorghum plus Acacia ssp. across the north-south transect (Fig. 2a), and from teff-wheat plus Faidherbia albida to teffmaize-sorghum plus Acacia tortilis Hayne (tadecha, or ajo loc) and Zizyphus mucronata Willd. (ourqura) across the west-east transects, while the livestock system is dominantly communal grazing of cattle and goats on farmland (Fig. 2b).

The sub-humid sites are characterized by rugged landscapes, with hills and valleys. Dominant crops are maize, sorghum, teff, nug (Guizotia abyssinica-an oil crop), with their relative importance varying with altitude and micro-climate. In contrast, diversity and types of trees species observed are heterogeneous across the north-south and east-south transects as well as by altitude (Teshome 2014). Croton macrostachyus Hochst. (bakanisa) is dominant in home compounds and farm boundaries in southwestern mid-highlands, 


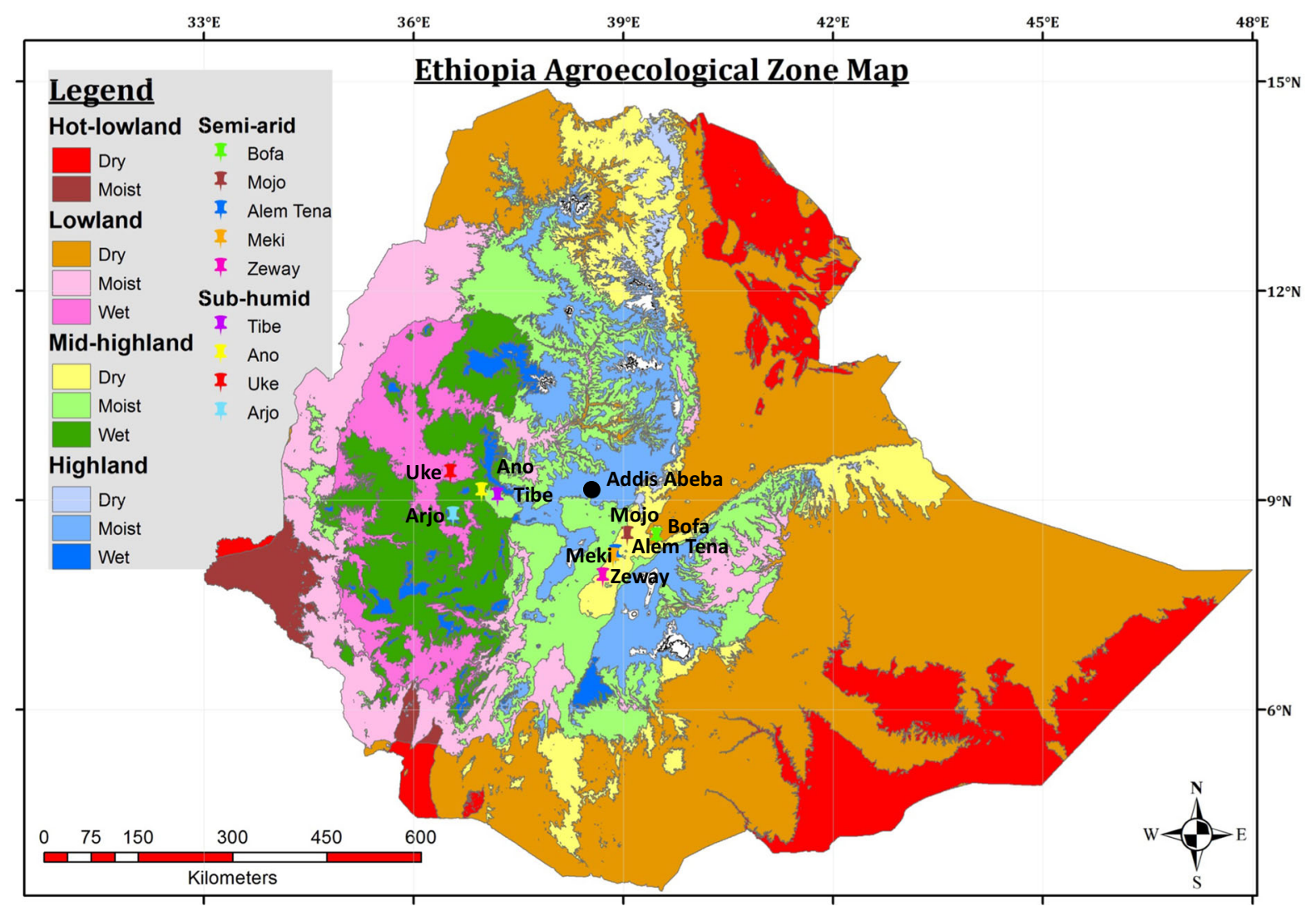

Fig. 1 Agroeclogical map of Ethiopia with locations of selected sites

Ficus spp. such as Ficus sycomorus (oda) and Ficus vasta Forssk (kiltu) in eastern mid-highlands, and Cordia africana Lam. (wadessa) in eastern parts, while small woodlots of Eucalyptus camaldulensis Dehnh. (bargamo dima) and scattered Acacia abysinica Hochst. (lafto) on farm are commonly observed (Fig. 2c). Across the east-west transect, fruits trees such as pawpaw, mangoes, and coffee are observed in home compound, along rivers or localities with irrigation structures available (Fig. 2d).

The administrative hierarchy of Ethiopia is the statezone-woreda. Woreda is equivalent to a district, within which there are a number of kebeles or villages. Five and four woredas were chosen from the semi-arid and sub-humid zones respectively, to reflect the transition of observed diversity in tree-crop systems. All five sites selected in the semi-arid zones were located in the drymidlands. In the sub-humid zones, two sites were in the wet mid-highlands, while the other two were in the moist midland and wet lowland respectively (Fig. 1). The selection of a kebeles was done in consultation with woreda administrative officers to be representative of each of the five woredas. A kebele is the smallest administrative unit in Ethiopia, in which households are registered and recorded. According to the 2007 Census, the population of a rural kebeles in Oromia varied widely from less than 100 to over a thousand households (Central Statistical Agency 2010), while the sizes reported by local officials for the surveyed kebeles ranged from about 300 to over a thousand households (Table 1). The minimum sample size of 568 out of 6135 households in all the selected kebeles was calculated using the formula of Israel (1992) for $\pm 4 \%$ precision level, while the minimum $10 \%$ of the households in each of the surveyed kebeles were targeted for interviews.

The socio-economic survey focused on collecting qualitative information about farmers' perceptions relating to the status of trees on farms as well as the income/asset status of households, while quantitative information about trees on farms was captured through a tree inventory for about a third of the households 

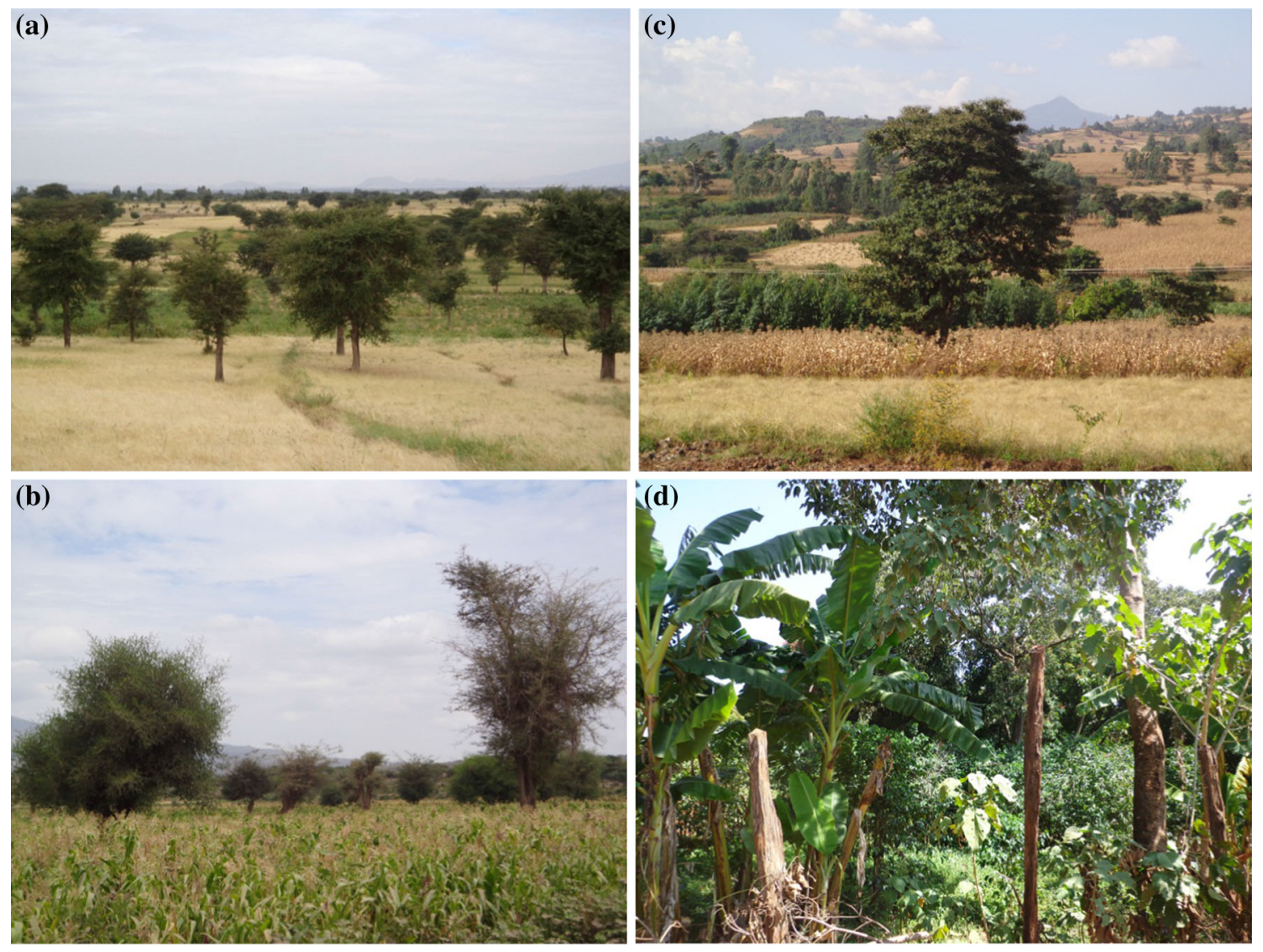

Fig. 2 Typical agroforestry practices observed in semi-arid and sub-humid zones of Oromia State, Central Ethiopia. a Faidherbia albida amongst teff in semi-arid Oromia. b Ziziphus mauritania

and Acacia abysinica in maize fields in semi-arid Oromia. c Cordia africana in a maize field in sub-humid Oromia. d Various trees around a homestead in sub-humid Oromia

surveyed. The inventory allows correction of any bias in householders' recollection regarding quantitative variables such as the number of trees on farm. The socio-economic data were collected between November and December 2012. A total of 687 households were interviewed across the two agroecologies. In most cases, the respondents were household heads or spouses who, combined, accounted for over $80 \%$ of surveyed households (Table 1). The data is made publicly available on DATAVERSE (http://hdl. handle.net/1902.1/21219 UNF:5:EwSwq3/7ysbpqpawnencvg == World Agroforestry Centre [Distributor] V21 [Version]).

Research questions and hypotheses

Patterns of tree cover on farm in Ethiopia, as elsewhere in SSA, are complex and heterogeneous in

terms of (1) mixture of species, (2) utilities derived from these species, (3) management intensity and niches occupied, under (4) specific biophysical and socio-economic circumstances (Nyaga et al. 2015). These dimensions correspond to criteria used to classify agroforestry practices: (1) structural, the nature and arrangement of components; (2) functional, the role and output derived from them; (3) socioeconomic, the type of management; and (4) agroecological, the zone where a system exists or is adoptable (Sinclair 1999).

Our major research question was how to characterize patterns of tree cover found on farms. More specifically, we propose a systematic method to identify patterns of tree cover on farms in terms of (1) species composition, (2) multiple utilities, (3) management intensity and niches occupied, and then identify fine-scale variation both ecological and socio- 


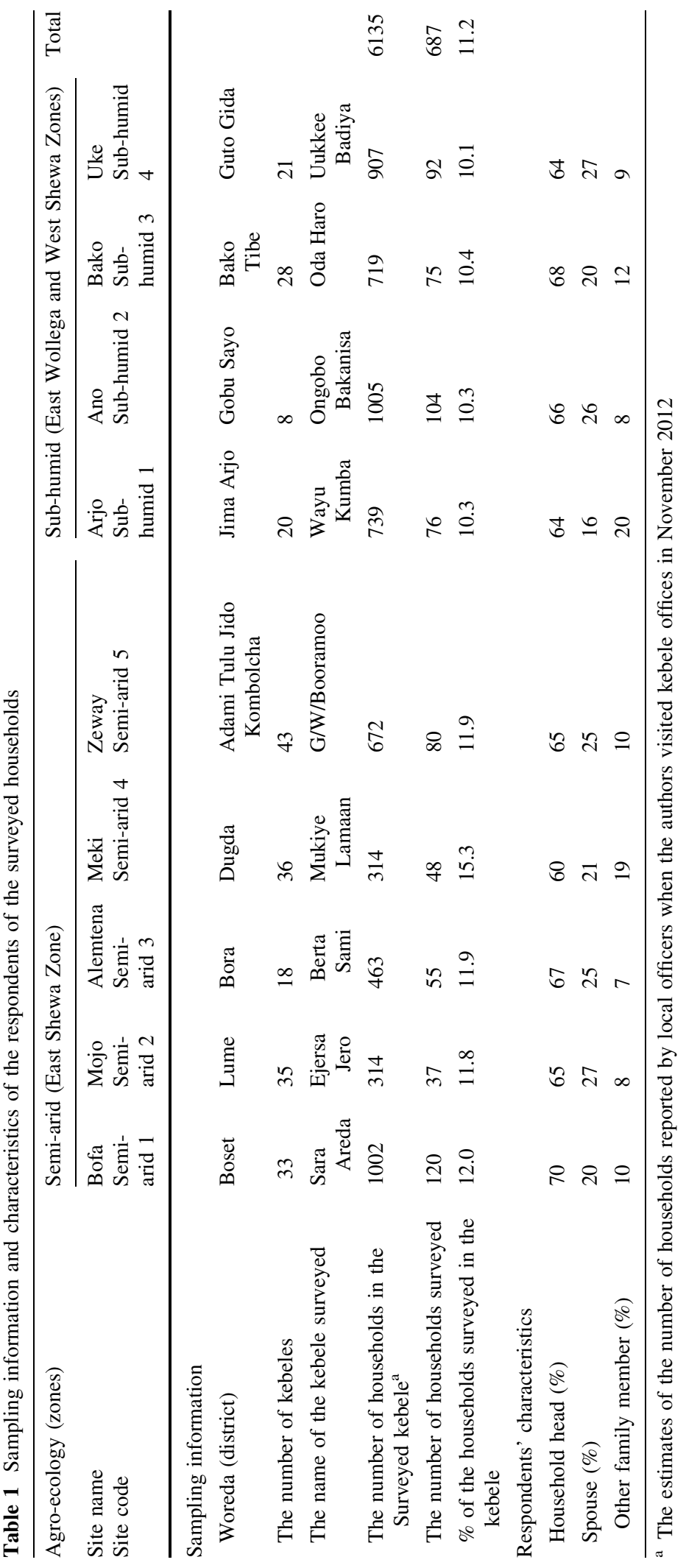


economic contextual factors that determine their adoption.

Our first major hypothesis was that farm households adopt portfolios of tree species that maximize utilities from goods and services derived from them, which, in turn, determine the appropriate management intensity and niches within the farm for the trees to occupy. We assume that the planting of tree species that produce high value fruits, fodder and timber is driven commercially, as they are deliberately planted and more intensively managed as an investment (Franzel and Shurr 2002). In contrast, we assume that native tree species naturally regenerated in agroforestry practices are managed less intensively but still serve multiple utilities, not only for direct consumption such as fuel and construction materials but also for ecosystem services such as shade and as windbreaks, soil fertility enhancement and soil erosion control (Poschen 1986; Biggelaar and Gold 1996).

Our second major hypothesis was that patterns of trees on farm are bounded by biophysical and socioeconomic conditions, which are classified into five major categories; biophysical factors, preferences, resource endowments, risk and uncertainty, and market incentives, following the definitions by Pattanayak et al. (2003). We discuss each of these, in turn.

Biophysical factors relate to influences on the physical production process associated with farming (Pattanayak et al. 2003). In our study area, East Shewa in the semi-arid zone is less agro-ecologically favored in terms of rainfall and soil than West Shewa/East Wollega in the sub-humid zone. A wide variety of tree species, including exotics, are likely to thrive in sub-humid conditions where intensive planting and management are feasible. In contrast, in semi-arid conditions, moisture stress constrains the survival of planted seedlings and well adapted native species are most likely to survive. While the five chosen semi-arid sites are all located in dry mid-highlands and relatively homogeneous in terms of topography, two of the sub-humid sites are located in higher, sloping conditions than the others, which may affect tree-crop management incentives.

Preferences are placeholders for the broad category of farmer specific influences such as risk tolerance, attitudes to conservation and intra-household homogeneity (Pattanayak et al. 2003). Because farmer preferences are difficult to measure explicitly, sociodemographic proxies such as age, gender, education, and social status are used instead. In an African context, gender of head of household may influence what trees are on a farm, because female headed households may take different decisions about managing trees than male-headed households. Traditional land/tree tenure systems often do not allow women to plant trees according to their own preference unless men approve, even though it is the women who bear the burden of taking care of raising trees and collecting firewood (Deininger et al. 2009). Family size and composition can also matter in terms of sufficiency and quality of labour to manage trees on farm while it is impossible to determine a priori the direction of the influence on adoption of this broad category (Pattanayak et al. 2003).

Risk and uncertainty reflect the unknowns in the market and institutional environment under which decisions are made. Given the long gestation period of investments in farming and forestry, lower risk and uncertainty will in general foster technological adoption (Pattanayak et al. 2003), while the extensive review of experiences from SSA indicate the ambiguity of such impacts which are highly context specific (Place 2009). For this study we include land, parcel characteristics and land-related policy and institutional experiences as proxy variables for risk and uncertainty. In Ethiopia, the land remains state owned while the constitution affirms the right of every adult access to land. The recent effort to improve security of land tenure in Ethiopia includes a land certification through decentralized mechanisms, where the regional government would issue land certificates to individual farmers (ARD Inc. 2004; Deininger et al. 2008, 2009). Experiences of land resettlements and "grabs" where the government designate certain areas for development, such as for irrigation schemes, outside investors or internal redistribution (Deininger et al. 2009; ARD Inc. 2004) can however influence tree planting positively or negatively depending on context. An interesting case was reported in Northern Ethiopia where tree planting was undertaken after land resettlement, as a way to visibly manifest land rights, whereas terracing was done in situations where there was a minimum level of tenure security (Deininger and Jin 2006). For Oromia state, only $39 \%$ of households were reported to receive the certificates several years after the program started in 2003-2004 (Deininger et al. 2008; Holden et al. 2011). Given this situation, the status of land tenure is expected to vary among the surveyed households with uncertain impacts on 
investment decisions. Communal grazing which is widely practiced in the country can also affect patterns of tree cover on farm. Communal grazing causes soil degradation but also affects the survival of tree seeds and seedlings on farms, which can affect incentives to intensify or extensify tree management on farms (Gebremedhin et al. 2004; Kassahun et al. 2009; Mekuria and Aynekulu 2013; Tesfaye et al. 2014). Under given tenure conditions, access to more land may provide locational flexibility for trees to be managed without competing with crops and livestock, if the availability of labour and other inputs is not constraining. Parcel fragmentation may have mixed effects. It may deter tree management efforts because of increased transaction costs associated with long distances between parcels and result in uneconomic operational holdings (Bizimana et al. 2004). In other contexts fragmentation may offer incentives for farmers to manage trees in some parcels or niches where soil types and slope conditions better match with trees rather than with crop and/or livestock farming, as a risk diversification and management strategy (Blarel et al. 1992).

Resource endowments measure the resources available to the technology adopter for implementing the new technology. Examples of resource endowments include asset holdings such as livestock and savings while we used proxy variables of diverse asset categories and farm/off-farm income categories. Generally, resource endowments are likely to be positively correlated with the probability of adoption. However, it is likely that different endowments will encourage different agroforestry practices (Pattanayak et al. 2003; Iiyama et al. 2008).

Market incentives include factors related to lower costs and/or higher benefits from technology adoption. In general, a factor that is expected to increase the net benefits associated with the technology is likely to be a positive influence on adoption (Pattanayak et al. 2003). In Ethiopia, markets designed specifically for agroforestry are rudimentary compared to those for crop/livestock (personal communication to Ethiopian partners). Therefore, how market access affects patterns of trees on farms are not known.

Data processing and analyses

In order to capture the complex roles of trees on farms, it is useful to develop a method to simultaneously capture multiple dimensions of patterns of tree use on farms, namely, species composition and their associated utilities, niches and management intensities. The socio-economic survey collected data about whether or not a farmer (a) raised seeds/seedlings; (b) planted seeds/seedlings; (c) protected naturally regenerated trees; or (d) had ever had trees on their farm, over the last three years. For the adoption categories with positive answers, farmers were further asked to provide names of tree species. Counts of different species were aggregated for each household with a mean of three different species per household. While 105 and 126 different tree species were counted in the semi-arid zone and sub-humid zone respectively, some species names reported in local languages were difficult to identify or have verified by Ethiopian botanists. At the same time, farmers often mentioned genus names only such as Acacia or Eucalyptus without specifying species. This potentially introduces problems in counting species diversity from farmers' recall, which needs to be verified by tree inventory.

Detailed questions were then asked about the farmers' reasons for adopting, and the utilities they derived from each tree species. Utilities were categorized into those with predominantly commercial value (timber, fruit, fodder, and medicine), subsistence (construction and tools for domestic purposes), fuel (firewood, charcoal), environmental services (shade, windbreaks, soil fertility, erosion control), fencing (either as live fences or poles), and other utilities (not categorized above). Often farmers provided more than two utilities for one species with the most important ranked as the primary utility and others as secondary. Farmers tend to rank higher or to give priorities to utilities from tangible goods, such as firewood, fruits, and timber, which contribute directly to consumption and income. Nevertheless, farmers tended to derive multiple ecosystem services from trees, including shade (microclimate), erosion control, and soil fertility enhancement.

While ranks represent an ordering of a list of items according to their importance for the particular issue under consideration, the lack of a standard scale makes the task of combining ranks over several farmers difficult (Abeyasekera 2001). Replacing ranks by scores enables variables to be treated like numerical data (The University of Reading Statistical Services Centre 2001). In order to quantitatively capture multiple utilities of trees on farm for different farmers, it is useful to derive 
Box 1 Formulae and rules for calculating and assigning weighted utility scores from ranks

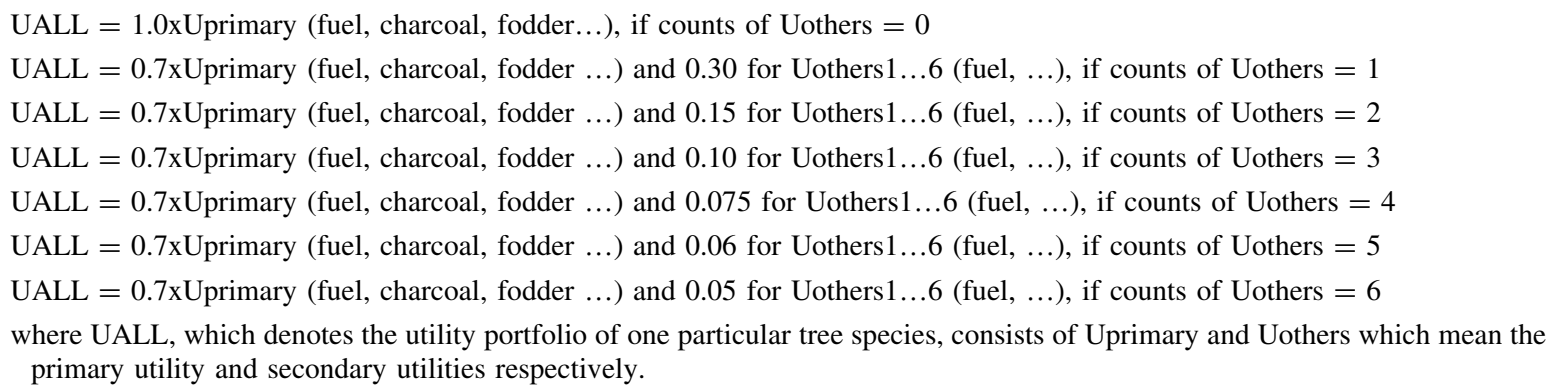

scores to reflect such multiple utilities of specific tree species. Scoring exercises are done on the basis of one identified criterion (Abeyasekera 2001), while the choice of scores is not critical, as long as the interpretations of results are insensitive to changes in the actual values attributed to ranks (The University of Reading Statistical Services Centre 2001). In our data, the farmers provided minimum zero to maximum six secondary utilities per tree species for the adoption category of "trees on farm over 3 years". Consequently, we arbitrarily set a score of 0.7 for the primary utility and a score of 0.3 to be divided among the secondary utilities as 0.3 is divisible by any number from one to six. We then calculated weighted utility scores for each tree species mentioned by a household, using the formulae and rules in Box 1.

For example, if a farmer said that fuel was the only one utility derived from his/her Acacia tortilis on farm, this species was given a score of 1.0 for fuel (firewood). If another farmer said that A. tortilis was primarily for fuel, but also for erosion control as another utility, then the species got 0.7 as the fuel score and 0.3 as the environmental services score. If two other utilities were mentioned, say soil control and fencing, aside from fuel as the primary utility, and then the species got 0.7 for fuel, 0.15 for erosion control and 0.15 for fencing. In this way, the score for one particular species could not exceed 1.0, but with higher numbers of utilities, scores would be subdivided amongst multiple utilities. Our formulae and rules are conceptually similar to the Utility Index (UI) proposed by Biggelaar and Gold (1996) while their index scores could add up to more than 1.0 if farmers reported many utilities for a single species.

Utility scores were aggregated by utility types for each household. Principal Component Analysis (PCA) was then used to derive independent component factors (where each component has zero correlation) from which patterns of tree diversity on farm were derived from species utilities and management intensities as we hypothesized that types of utility determine management intensity.

Another important dimension of patterns of trees on farm are the niches that specific tree species occupysuch as, scattered on farm, on boundaries, as live fences or hedges within fields or as soil conservation bunds, woodlots, in home compounds or fallows. The association between the niches for specific tree species and principal component scores were used to develop utility/management intensity patterns through Pearson correlation analysis.

Once proxy variables for distinctive patterns of trees on farm were derived, regression analyses were employed to determine which agroecological and socio-economic factors affected their adoption. Ordinary Least Squares (OLS) regression was used to estimate the association between the dependent variables-normalized scores calculated for each PCA component representing different patterns of trees on farms - and the explanatory variables. Descriptive statistics of the explanatory variables considered for the regression models are summarized in Table 2.

\section{Results and discussion}

Tree adoption strategies

Table 3 presents, regardless of the adoption categories, in the semi-arid zone, Acacia species, especially A. tortilis, A. senegal (kertefa) A. etbaica (dodoti) that were commonly mentioned along with 
Table 2 Descriptive statistics of explanatory variables by agroecological zones

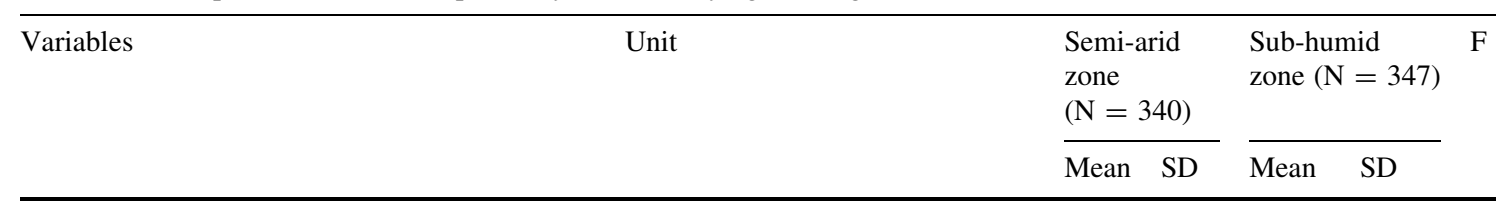

Ecological/topographical condition

Mid-highland dummy

Wet mid-highland $=1$,

$0.5 \quad 0.5$

$365.40 * * *$

Household composition

Head gender dummy others $=0$

Head education level

Male $=1$, female $=0$

0.9

0.3

0.9

0.3

0.21

Total family size

No formal education $=0, \ldots$

0.7

0.7

0.7

0.7

0.16

number

$\begin{array}{llll}6.7 & 3.1 & 6.1 & 2.5\end{array}$

$5.90 * *$

Male ratio

$\%$ In total family size

$\begin{array}{llll}0.5 & 0.2 & 0.5 & 0.2\end{array}$

1.58

Working age member ratio

$\%$ In total family size

$\begin{array}{llll}0.4 & 0.2 & 0.5 & 0.2\end{array}$

0.66

Land/parcel access, characteristics, policy experiences

Total land size

Hectare

$\begin{array}{llll}3.7 & 11.1 & 1.9 & 5.8\end{array}$

$6.89 * * *$

Parcel fragmentation (Simpson index)

Simpson Index

Mean distance of parcels from homesteads

m

Proportion of parcels owned with certificate

$\%$ Size in total land size

Proportion of parcels owned without certificate

Proportion of parcels rented from others

$\%$ Size in total land size

$\%$ Size in total land size

$\begin{array}{llll}0.5 & 0.2 & 0.4 & 0.3\end{array}$

$21.13 * * *$

Proportion of parcels on sloped/steep land

$\%$ Size in total land size

$\begin{array}{llll}1482 & 1411 & 1093 & 1389\end{array}$

$13.30 * * *$

Experience of free communal livestock grazing

Experience of land resettlement

Affected $=1$, not affected $=0$

0.8

$0.8 \quad 0$.

0.7

0.4

1.81

0

0.

.10 .3

30.1

1.55

0.26

$\begin{array}{llll}0.1 & 0.3 & 0.5 & 0.4\end{array}$

$188.82 * * *$

$\begin{array}{llll}0.3 & 0.5 & 0.6 & 0.5\end{array}$

$49.17 * * *$

Affected $=1$, not affected $=0$

$\begin{array}{llll}0.0 & 0.2 & 0.0 & 0.2\end{array}$

0.54

Affected $=1$, not affected $=0$

$\begin{array}{lll}0.4 & 0.5 & 0.6\end{array}$

0.5

$17.09 * * *$

Asset/income diversification

$$
\begin{aligned}
& \text { Livestock-local animals } \\
& \text { Livestock-exotic animals } \\
& \text { Asset-domestic asset value } \\
& \text { Asset-communication asset value } \\
& \text { Asset-transport asset value } \\
& \text { Asset-farm asset value }
\end{aligned}
$$

Farm income- cereal \& pulse

Farm income-cash crops

Farm income-roots \& tubers

Farm income-animal

Farm income-tree-based

Off-farm income-regular business

Off-farm income-casual

Off-farm income-remmitance \& gift

Off-farm income-loan

Off-farm income-rent

Access to extension services, markets, infrastructure

$\begin{array}{ll}\text { Participation in field school } & \text { Yes }=1, \text { no }=0 \\ \text { Participation in training } & \text { Yes }=1, \text { no }=0 \\ \text { Participation in field day } & \text { Yes }=1, \text { no }=0\end{array}$

FAO Livestock Unit

FAO Livestock Unit

Estimated value in USD

Estimated value in USD

Estimated value in USD

Estimated value in USD

Aggregated scores ${ }^{a}$

Aggregated scores ${ }^{a}$

Aggregated scores ${ }^{\mathrm{a}}$

Aggregated scores ${ }^{\mathrm{a}}$

Aggregated scores ${ }^{\mathrm{a}}$

Aggregated scores ${ }^{\mathrm{b}}$

Aggregated scores ${ }^{\mathrm{b}}$

Aggregated scores ${ }^{\mathrm{b}}$

Aggregated scores ${ }^{\mathrm{b}}$

Aggregated scores ${ }^{\mathrm{b}}$

\begin{tabular}{llllc}
6.0 & 10.0 & 3.8 & 3.8 & $14.64 * * *$ \\
0.1 & 0.9 & 0.0 & 0.5 & 1.74 \\
78 & 280 & 31 & 96 & $8.84 * * *$ \\
65 & 97 & 22 & 31 & $60.67 * * *$ \\
60 & 117 & 11 & 70 & $43.80^{* * * *}$ \\
273 & 200 & 238 & 152 & $6.77 * * *$ \\
3.4 & 0.9 & 2.5 & 1.0 & $178.63^{* * * *}$ \\
0.4 & 0.8 & 1.7 & 1.6 & $190.82^{* * *}$ \\
0.0 & 0.1 & 0.3 & 0.7 & $76.13^{* * *}$ \\
2.0 & 1.6 & 1.5 & 1.3 & $17.48^{* * *}$ \\
0.9 & 0.9 & 1.5 & 1.4 & $53.24 * * *$ \\
0.4 & 0.6 & 0.5 & 0.6 & 0.32 \\
0.3 & 0.5 & 0.3 & 0.5 & 2.29 \\
0.1 & 0.3 & 0.1 & 0.3 & 0.13 \\
0.4 & 0.6 & 0.6 & 0.7 & $11.83^{* * *}$ \\
0.2 & 0.4 & 0.1 & 0.4 & $4.34 * *$ \\
& & & & \\
0.0 & 0.2 & 0.0 & 0.1 & 1.12 \\
0.2 & 0.4 & 0.2 & 0.4 & $3.53^{*}$ \\
0.4 & 0.5 & 0.3 & 0.4 & $5.95^{* *}$ \\
\hline & & & &
\end{tabular}


Table 2 continued

\begin{tabular}{|c|c|c|c|c|c|c|}
\hline \multirow[t]{2}{*}{ Variables } & \multirow[t]{2}{*}{ Unit } & \multicolumn{2}{|c|}{$\begin{array}{l}\text { Semi-arid } \\
\text { zone } \\
(\mathrm{N}=340)\end{array}$} & \multicolumn{2}{|c|}{$\begin{array}{l}\text { Sub-humid } \\
\text { zone }(\mathrm{N}=347)\end{array}$} & \multirow[t]{2}{*}{$\mathrm{F}$} \\
\hline & & Mean & SD & Mean & SD & \\
\hline Participation in field visit & Yes $=1$, no $=0$ & 0.6 & 0.5 & 0.6 & 0.5 & 0.13 \\
\hline Participation in demonstration farm & Yes $=1$, no $=0$ & 0.4 & 0.5 & 0.3 & 0.5 & $7.83 * * *$ \\
\hline Participation in interaction & Yes $=1$, no $=0$ & 0.5 & 0.5 & 0.6 & 0.5 & $3.88 * *$ \\
\hline Participation in community meetings & Yes $=1$, no $=0$ & 0.8 & 0.4 & 0.9 & 0.3 & $4.70 * *$ \\
\hline Participation in training centres & Yes $=1$, no $=0$ & 0.9 & 0.3 & 0.9 & 0.3 & 1.68 \\
\hline Distance to output market & $\mathrm{m}$ & 4454 & 3442 & 4449 & 3505 & .000 \\
\hline Distance to mortable road & $\mathrm{m}$ & 569 & 1119 & 1377 & 2166 & $37.19 * * *$ \\
\hline Distance to tarmac road & $\mathrm{m}$ & 4830 & 6279 & 16,683 & 21,330 & $92.03 * * *$ \\
\hline Distances to markets and roads & Factor scores ${ }^{c}$ & $(0.3)$ & 0.6 & 0.2 & 1.2 & $32.72 * * *$ \\
\hline
\end{tabular}

a Aggregated scores for relevant farm produce categories during the last 12 months; $0=$ not produced, $1=$ produced\&consumed, 2 = if produced\&sold for cash

b Aggregated scores for relevant off-farm income activities involvement during the last 12 months; $0=$ not engaged, $1=$ engaged and earned income

${ }^{c}$ Factor scores were derived from variables of distances to markets, roads and infrastructure by principal component analysis

Zizyphus mucronata, Faidherbia albida, and Balanties aegyptiaca (bedeno). Table 4 shows that in the sub-humid zone, Cordia africana, Croton macrostachyus, Vernonia amygdalina (ebicha), Mangifera indica and Eucalyptus spp., especially E. camaldulensis were commonly mentioned. At the same time there was high variability of the proportion of households adopting these tree species across sites within each agroecological zone. For example, the adoption rate of Acacia tortilis ranged between 52 and $78 \%$ across sites of the semi-arid zone, while that of Cordia africana varied between 38 and $67 \%$ across the sub-humid zone.

Table 5 presents the descriptive statistics of variables indicating strategies of tree adoption on farms. The semi-arid zone had a lower proportion of households who adopted raising seedlings ( $4 \%$, on average 0.11 species per farm) and planting trees $(36 \%, 0.88$ species per farm) than the sub-humid zone (29\%, 0.46 species per farm for raising seedlings, and $71 \%, 2.03$ species per farm for planting trees), while a higher proportion of households protected (84\%, 2.49 species) naturally regenerated trees on farm than that of the sub-humid zone (73\%, 1.96 species). Overall, $92 \%$ of the surveyed households in the semi-arid zone reported having trees on their farm with a mean of 3.37 tree species, compared to $86 \%$ of households with a mean of 3.50 tree species per farm in the sub-humid zone. In terms of tree niches on farm, higher numbers of species were found scattered in crop fields both for the semi-arid (2.14 species) and sub-humid zones (1.67 species), followed by home compounds and external boundaries or live fences. In both zones, fuel was the most frequent utility ( 1.22 weighted utility scores in the semi-arid zone and 1.01 in the sub-humid zone). For other utilities, the sub-humid zone households gave higher weighted utility scores for highvalue commercial species ( 0.90 scores) than those in the semi-arid zones ( 0.23 scores), who in turn gave higher scores for environmental services ( 0.96 scores) than their sub-humid counterparts ( 0.70 scores).

Table 6 shows that some of the variables describing tree adoption on farm in Table 4 were highly correlated. For example, households who produced seedlings were more likely to plant trees, which was then positively associated with utilities from high-value species but negatively with utilities from fuel and environmental services. On the other hand, the number of existing species on farm was positively correlated with all utility types, but especially with woodfuel and environmental services, as well as an establishment by naturally regenerating and protecting trees.

Table 7 summarizes the result of the PCA analysis. Four of the extracted components explained about $59 \%$ of the total variance of the original variables included. These four components were interpreted 
Table 3 Proportion of households with the ten most common tree species on farm in the semi-arid sites

\begin{tabular}{|c|c|c|c|c|c|c|c|c|c|}
\hline Rank. & Tree species name & $\begin{array}{l}\text { Vernacular name in the } \\
\text { local language(Oromiffa) }\end{array}$ & $\begin{array}{l}\text { Site } \\
\text { name } \\
\text { Site } \\
\text { code } \\
\text { Sample } \\
\text { size }\end{array}$ & $\begin{array}{l}\text { Bofa } \\
\text { Semi- } \\
\text { arid1 } \\
120\end{array}$ & $\begin{array}{l}\text { Mojo } \\
\text { Semi- } \\
\text { arid2 } \\
37\end{array}$ & $\begin{array}{l}\text { Alemtena } \\
\text { Semi- } \\
\text { arid3 } \\
55\end{array}$ & $\begin{array}{l}\text { Meki } \\
\text { Semi- } \\
\text { arid4 } \\
48\end{array}$ & $\begin{array}{l}\text { Zeway } \\
\text { Semi- } \\
\text { arid5 } \\
80\end{array}$ & Total \\
\hline 1 & Acacia tortilis Hayne & Tadecha, Ajo $^{a}$ & & 78 & 70 & 60 & 52 & 74 & 70 \\
\hline 2 & Zizyphus mисronata Willd. & Qurqura & & 68 & 24 & 31 & 13 & 5 & 35 \\
\hline 3 & $\begin{array}{l}\text { Faidherbia albida (syn. } \\
\text { Acacia albida Delile) } \\
\text { A.Chev }\end{array}$ & Gerbi & & 13 & 73 & 36 & 40 & 8 & 26 \\
\hline 4 & Acacia senegal Willd. & Kertefa & & 37 & 5 & 24 & 17 & 23 & 25 \\
\hline 5 & Balanites aegyptiaca Delile & Bedeno & & 18 & 32 & 16 & 21 & 28 & 22 \\
\hline 6 & Acacia etbaica Schweinf. & Dodoti $^{\mathrm{b}}$ & & 18 & 54 & 29 & 4 & 4 & 18 \\
\hline 7 & $\begin{array}{l}\text { Croton macrostachyus } \\
\text { Hochst. }\end{array}$ & Bakanisa & & - & 14 & 38 & 42 & 1 & 14 \\
\hline 8 & Melia azedarach $\mathrm{L}$. & Nimi & & 19 & 3 & 20 & 13 & 6 & 14 \\
\hline 9 & $\begin{array}{l}\text { Eucalyptus camaldulensis } \\
\text { Dehnh. }\end{array}$ & Bargamo Dima & & 13 & 16 & 13 & 4 & 3 & 10 \\
\hline 10 & $\begin{array}{l}\text { Dichrostachys cinerea (L.) } \\
\text { Wight \& Arn. }\end{array}$ & Hatte & & 4 & 24 & 11 & 4 & 3 & 7 \\
\hline
\end{tabular}

The most commonly identified/observed species in the study sites grow over $5 \mathrm{~m}$, thus we define them as trees not shrubs, according to the FAO (2012) definition

a Acacia tortilis is locally called Tadecha in many parts of semi-arid Oromia, while the same species is called Ajo loc in Zeway

b Dodoti can either refer to Acacia gerrardi or Acacia etbaica, while the tree inventory study by Endale (2014) in the semi-arid sites reported only Acacia etbaica. Hence, the references to Dodoti in the semi-arid zones were counted for Acacia etbaica

with variables of high factor loadings, as follows. Component 1 had high loadings for the number of natural regenerated and protected species, utilities for subsistence, woodfuel, environmental services and fencing. Therefore Component 1 was taken to represent farmer managed natural regeneration of trees on farm largely for subsistence, woodfuel, environmental services and fencing (FMNR). Component 2 with higher factor loadings of raising seedlings, planting trees, and utilities for high commercial values was taken to represent active planting high value agroforestry species (HVAF). Component 4 indicates agroforestry practices with focus on environmental services but without fencing, while Component 3 seemingly captured cases in which farmers did not specify utilities derived from specific tree species. Interpretations of Component 1 (FMNR) and Component 2 (HVAF) confirm our assumptions that tree species adopted in indigenous practices are managed less intensively than economically important species but serve for multiple utilities such as fuel and ecosystem services simultaneously (Biggelaar and Gold 1996), while deliberate tree planting is associated with species of high economic utility (Franzel and Sherr 2002).

Figure 3 presents the distribution of the derived principal component scores for households by study sites. Despite variances, the sub-humid sites in general have higher scores for Component 2 (HVAF) than those in semi-arid sites, while the intra-site variability seems larger than the inter-site difference for Component 1 (FMNR) score. The inter-site trends or differences are even less clear for Components 3 (OTHERS) and 4 (ENV-FENCE) with many outliers observed.

Table 8 shows the correlations between the derived component scores and niches for trees on farms. Component 1 or FMNR for example had a high association with scattered on farm niches but also significant associations with other niches, including home compounds, hedges in fields and field boundaries. In contrast, Component 2 or HVAF had 
Table 4 Proportion of households with the 10 most common tree species on farm in the sub-humid sites

\begin{tabular}{|c|c|c|c|c|c|c|c|c|}
\hline Rank & Tree species name & $\begin{array}{l}\text { Vernacular name } \\
\text { in the local } \\
\text { language } \\
\text { (Oromiffa) }\end{array}$ & $\begin{array}{l}\text { Site name } \\
\text { Site code } \\
\text { Sample } \\
\text { size }\end{array}$ & $\begin{array}{l}\text { Arjo } \\
\text { Sub- } \\
\text { humid1 } \\
76\end{array}$ & $\begin{array}{l}\text { Ano } \\
\text { Sub- } \\
\text { humid2 } \\
104\end{array}$ & $\begin{array}{l}\text { Bako } \\
\text { Sub- } \\
\text { humid3 } \\
75\end{array}$ & $\begin{array}{l}\text { Uke } \\
\text { Sub- } \\
\text { humid4 } \\
92\end{array}$ & Total \\
\hline 1 & Cordia africana Lam. & Wadessa & & 38 & 63 & 67 & 48 & 54 \\
\hline 2 & $\begin{array}{l}\text { Eucalyptus camaldulensis } \\
\text { Dehnh. }\end{array}$ & Bargamo Dima & & 36 & 46 & 55 & 28 & 41 \\
\hline 3 & $\begin{array}{l}\text { Croton macrostachyus } \\
\text { Hochst. }\end{array}$ & Bakanisa & & 46 & 51 & 36 & 14 & 37 \\
\hline 4 & Vernonia amygdalina Delile & Ebicha & & 22 & 22 & 35 & 33 & 28 \\
\hline 5 & Mangifera indica Wall. & Mango & & 3 & 20 & 17 & 20 & 16 \\
\hline 6 & Albizia gummifera C.A.Sm. & Mukarba & & 33 & 15 & 5 & 4 & 14 \\
\hline 7 & Syzygium guineense DC. & Badessa & & 12 & 12 & 7 & 25 & 14 \\
\hline 8 & Ficus sycomorus & Oda & & 11 & 17 & 3 & 11 & 11 \\
\hline 9 & Acacia abyssinica Hochst. & Lafto & & 13 & 13 & 5 & - & 8 \\
\hline 10 & $\begin{array}{l}\text { Calpurnia aurea (Lam.) } \\
\text { Benth. }\end{array}$ & Checka & & - & 16 & 9 & - & 7 \\
\hline 10 & Vernonia auriculifera Hiern & Reji & & 16 & 6 & 5 & 2 & 7 \\
\hline 10 & Ficus vasta Forssk. & Kiltu & & 1 & 13 & 8 & 3 & 7 \\
\hline
\end{tabular}

The most commonly identified/observed species in the study sites grow over $5 \mathrm{~m}$, thus we define them as trees not shrubs, according to the FAO (2012) definition

significant and positive correlations only with home compounds and field boundaries. The relations amongst contextual factors and FMNR confirm our assumption that traditional agroforestry practices are driven by locational flexibility along with multiple utilities, as Biggelaar and Gold (1996) argued from their Rwandan case study. In contrast, the relations amongst contextual variables and HVAF could be explained by the fact that it would be easy for farmers to manage and supervise the growing of commercially valuable tree species in home compounds and fences, whereas scattered trees on farm would be susceptible to low survival rates because of livestock grazing (Gebremedhin et al. 2004; Kassahun et al. 2009; Mekuria and Aynekulu 2013; Tesfaye et al. 2014). This is consistent with the logic behind the homegardens widely observed in southern as well as northwestern regions of Ethiopia, which are known for their rich diversity of economically useful tree species that shade enset (Ensete ventricosum, also known as false banana) and/or coffee (Negash 2007; Hylander and Nemomissa 2008; Linger 2014). On the other hand, the association between Component 3 (other, nonclassified utilities) and other niches, along with the negative relation of Component 4 (environmental services without fence) and external boundary, would not provide much insight.

Factors affecting the adoption of different strategies

Table 9 presents the results of the regression analyses. Factors significantly affecting the adoption of FMNR included: being in the semi-arid zone, on mid-land, with larger family size, higher ratios of males and working-age members, larger total land size, larger proportion of parcels on sloped land, higher incomes from cereals, pulses and rent; experiences of communal grazing and tenure upgrading, access to training/training centres, and longer distances to markets. FMNR was negatively correlated with field days/community meetings. In contrast, variables found significantly positively associated with HVAF included: being in the sub-humid zone, having a higher proportion of owned land without certificate, higher farm asset values, higher tree-based farm income, regular business off-farm income, field days and proximity to markets. Variables such as higher transport asset 
Table 5 Extent, form and utility of trees adopted by agroecological zone

\begin{tabular}{llll}
\hline & Unit & $\begin{array}{l}\text { Semi-arid zone } \\
(\text { cases }=340)\end{array}$ & $\begin{array}{l}\text { Sub-humid } \\
\text { zone(cases }=347)\end{array}$ \\
& Mean $\begin{array}{l}\text { Std. } \\
\text { Deviation }\end{array}$ & $\begin{array}{l}\text { Mean } \\
\text { Std. } \\
\text { Deviation }\end{array}$ \\
\hline
\end{tabular}

Trees on Farm

Proportion of parcels with trees planted

Establishment method

Raised seeds/seedlings during the last 3 years

Planted trees during the last 3 years

Protected naturally regenerated trees during the last 3 years

Having trees over 3 years old on farm

Tree niches on farm

Scattered in crop farm

External boundary/live fence

Hedges within farm/soil conservation bonds

Woodlot

Home compound

Fallow land

Others/NA

Utilities

High value commercial species types

Subsistence species types

Woodfuel species types

Environmental service species types

Fence species types

Other species types

$$
\begin{aligned}
& \text { Mean proportion in total } \\
& \text { parcels }
\end{aligned}
$$

$.19 \quad .28$

$.47 \quad .35$

$130.15^{* * *}$

Proportion of households

$\begin{array}{ll}.04 & .20 \\ .11 & .58\end{array}$

$.29 \quad .45$

$84.83 * * *$

Mean number of species types

Proportion of households

$.36 \quad .48$

.46

1.13

$27.20 * * *$

Mean number of species types

Proportion of households

$.88 \quad 1.57$

.71

.45

$96.24 * * *$

$65.95 * * *$

Proportion of households

Mean number of species types

Proportion of households

$.84 \quad .37$

$2.03 \quad 2.10$

$12.82 * * *$

$2.49 \quad 1.62$

$.73 \quad .45$

$14.04 * * *$

Mean number of species types

$\begin{array}{rr}.92 & .27 \\ 3.37 & 2.18\end{array}$

$1.96 \quad 2.04$

$6.89 * * *$

$.86 \quad .35$

$3.50 \quad 2.59$

0.47

Mean number of species types

Mean number of species types

Mean number of species types

Mean number of species types

Mean number of species types

Mean number of species types

Mean number of species types

$2.14 \quad 2.01$

$1.67 \quad 2.06$

$9.17 * * *$

$0.16 \quad 0.52$

$0.36 \quad 0.81$

$15.03 * * *$

$0.09 \quad 0.48$

$0.07 \quad 0.52$

0.18

$0.11 \quad 0.64$

$0.08 \quad 0.37$

0.61

$0.68 \quad 1.40$

$1.19 \quad 1.67$

$18.42 * * *$

$0.03 \quad 0.44$

$0.10 \quad 0.57$

$3.65^{*}$

$0.16 \quad 0.74$

0.02

0.13

11.85

Mean scores of weighted utilities

Mean scores of weighted utilities

Mean scores of weighted utilities

Mean scores of weighted utilities

Mean scores of weighted utilities

Mean scores of weighted utilities
$.23 \quad 56$

$.90 \quad 1.28$

$.43 \quad .65$

$1.01 \quad 1.17$

$1.22 \quad 1.28$

$.99 \quad 1.12$

.70

.92

$13.02 * * *$

$.47 \quad .74$

.36

.65

$4.39 * *$

.17

.60

$.09 \quad .38$

$4.18 * *$

*** Significant at $1 \%$; ** significant at $5 \%$; significant at $1 \%$. 
Table 6 Associations amongst variables describing tree adoption patterns

\begin{tabular}{|c|c|c|c|c|c|c|c|c|c|}
\hline $\begin{array}{l}\text { No. of } \\
\text { species } \\
\text { whose } \\
\text { seeds/ } \\
\text { seedlings } \\
\text { were } \\
\text { raised }\end{array}$ & $\begin{array}{l}\text { No. of } \\
\text { species } \\
\text { which } \\
\text { were } \\
\text { planted }\end{array}$ & $\begin{array}{l}\text { No. of } \\
\text { species } \\
\text { which } \\
\text { were } \\
\text { naturally } \\
\text { regenerated } \\
\text { and } \\
\text { protected }\end{array}$ & $\begin{array}{l}\text { No. of } \\
\text { species } \\
\text { over } \\
3 \text { years } \\
\text { old on } \\
\text { farm }\end{array}$ & $\begin{array}{l}\text { Scores } \\
\text { for } \\
\text { species } \\
\text { types by } \\
\text { utility for } \\
\text { high } \\
\text { commer- } \\
\text { cial value }\end{array}$ & $\begin{array}{l}\text { Scores } \\
\text { for } \\
\text { species } \\
\text { types by } \\
\text { utility for } \\
\text { subsistence } \\
\text { use }\end{array}$ & $\begin{array}{l}\text { Scores } \\
\text { for } \\
\text { species } \\
\text { types by } \\
\text { utility } \\
\text { for } \\
\text { woodfuel }\end{array}$ & $\begin{array}{l}\text { Scores } \\
\text { for } \\
\text { species } \\
\text { types by } \\
\text { utility } \\
\text { for } \\
\text { environ- } \\
\text { mental } \\
\text { services }\end{array}$ & $\begin{array}{l}\text { Scores } \\
\text { for } \\
\text { species } \\
\text { types } \\
\text { by } \\
\text { utility } \\
\text { for } \\
\text { fence }\end{array}$ & $\begin{array}{l}\text { Scores } \\
\text { for } \\
\text { species } \\
\text { types } \\
\text { by } \\
\text { utility } \\
\text { other } \\
\text { than } \\
\text { above }\end{array}$ \\
\hline
\end{tabular}

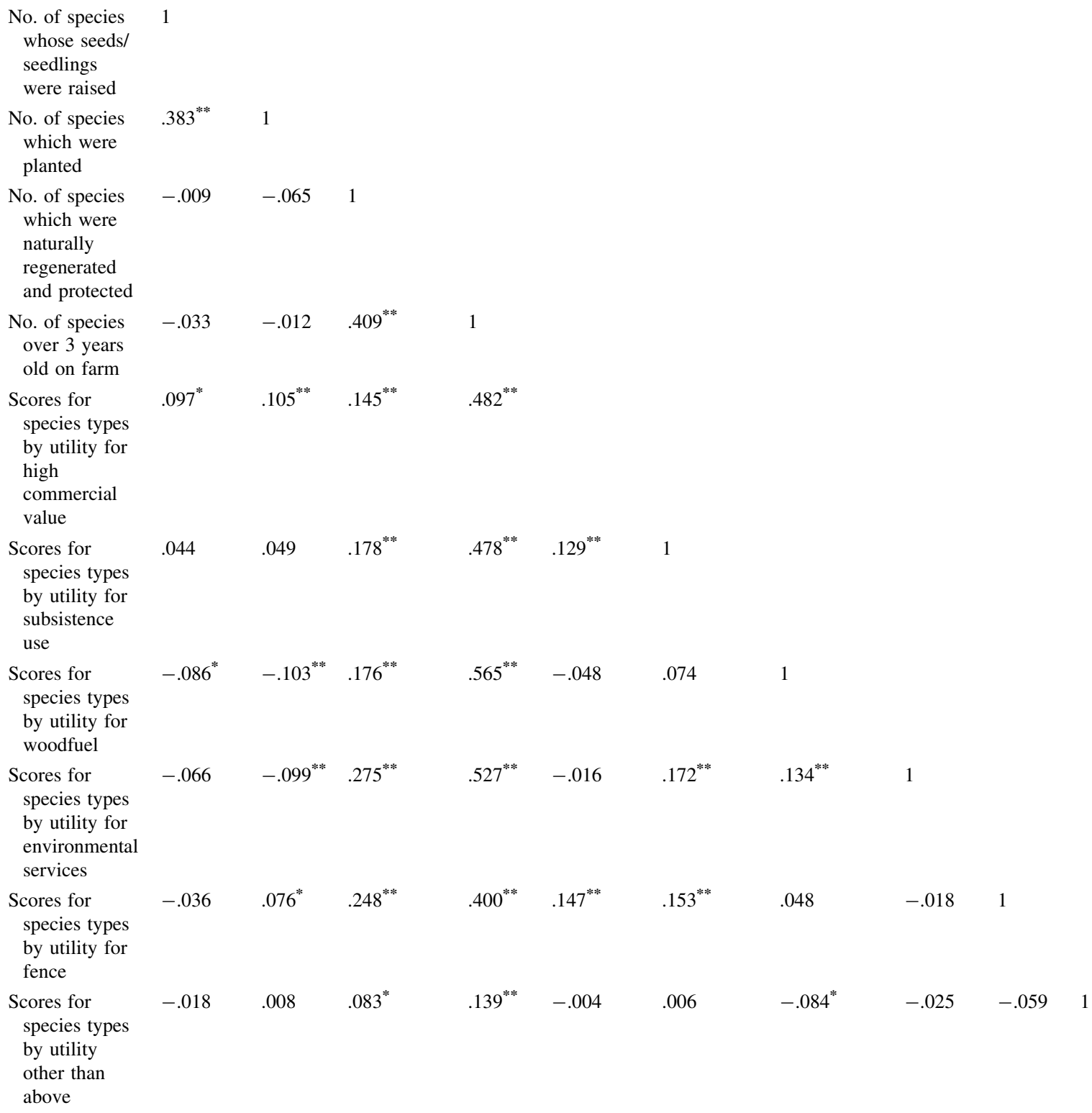

* Correlation is significant at the 0.05 level (2-tailed) 
Table 7 Derived components representing tree adoption strategies

\begin{tabular}{|c|c|c|c|c|c|}
\hline \multirow[t]{2}{*}{ Normalized scores } & \multirow[t]{2}{*}{ Extraction } & \multicolumn{4}{|c|}{ Principal Component } \\
\hline & & 1 & 2 & 3 & 4 \\
\hline No. of species whose seeds/seedlings were raised during the last 3 years & .700 & -.192 & 689 & -.167 & .402 \\
\hline No. of species which were planted during the last 3 years & .642 & -.203 & .737 & -.129 & .203 \\
\hline $\begin{array}{l}\text { No. of species which were naturally regenerated and protected during the last } \\
3 \text { years }\end{array}$ & .588 & .734 & .102 & .189 & .060 \\
\hline Scores for species types by utility for high commercial value & .445 & .257 & .485 & .158 & -.344 \\
\hline Scores for species types by utility for subsistence use & .367 & .518 & .281 & .014 & .142 \\
\hline Scores for species types by utility for woodfuel & .453 & .439 & -.246 & -.422 & .150 \\
\hline Scores for species types by utility for environmental services & .626 & .558 & -.169 & -.037 & .533 \\
\hline Scores for species types by utility for fence & .654 & .456 & .308 & -.048 & -.591 \\
\hline Scores for species types by utility other than above & .823 & -.020 & .017 & .881 & .215 \\
\hline Total Variance Explained ( $\%$ of variance) & & 18.48 & 16.95 & 11.82 & 11.64 \\
\hline Cumulative (\%) & & 18.48 & 35.43 & 47.25 & 58.89 \\
\hline
\end{tabular}

values, farm incomes from roots and tubers, and animals, off-farm income from casual activities and loans, experiences of communal grazing, and community meetings had negative associations with HVAF.

As we had assumed, biophysical factors were found to influence the adoption of different strategies. There is a higher likelihood of adopting HVAF in the subhumid zone through planting tree species with timber and fruit utility. In contrast, FMNR was highly associated with the semi-arid zone, probably because harsh climatic conditions may discourage farmers from investing in active tree planting because of low survival rates of seedlings. The significant positive sign of the mid-highland dummy, which applies to two out of four sites in the sub-humid zone, for FMNR, indicates that FMNR is also practiced in the subhumid zone, especially in the mid-highland parts. Figure 3 also indicates that tree adoption strategies have high variability amongst households within the same agroecological zone.

Controlling biophysical factors, preference, risk and uncertainty, and resource endowment factors have contrasting effects on the adoption of FMNR and HVAF.

Labor availability, especially the proportion of male labor, and land availability, are significant factors for FMNR but not constraints for HVAF, while the gender and education level of the household heads are found not significant for both strategies. As FMNR requires extensive management of trees on farm though occasionally pollarding and lopping, a large land size with a large number of family members supplying labor may provide an advantage for households to allocate more labor that is required for FMNR activities over extensive fields. In turn, HVAF, which is associated with homesteads and boundaries, can be managed without being constrained by land and family labor sizes.

Land access conditions and management/policy experiences which are proxy variables for risk and uncertainty also affected the likelihoods of adopting FMNR and HVAF differently. Land ownership provided a positive incentive to adopt HVAF, even without formal certificates in the Oromia context where the certification program had started but the issuing of certificates had not been fully completed. But, land ownership did not significantly affect adoption of FMNR, which still has a positive association with farmer's experience of upgrading their tenure. It is interesting to note that HVAF had negative association with communal grazing, while with FMNR it was positive. In the Ethiopian context, under communal grazing, neighboring farmers free their cattle and goats to browse on crop fields after communal harvesting. It can be interpreted that promoting intensive agroforestry of actively planted tree species for timber, fruit and income crops requires not only favorable agroecological conditions, but also institutional/policy arrangements to set up physical fencing or institutional arrangements of social fencing to protect young trees. 

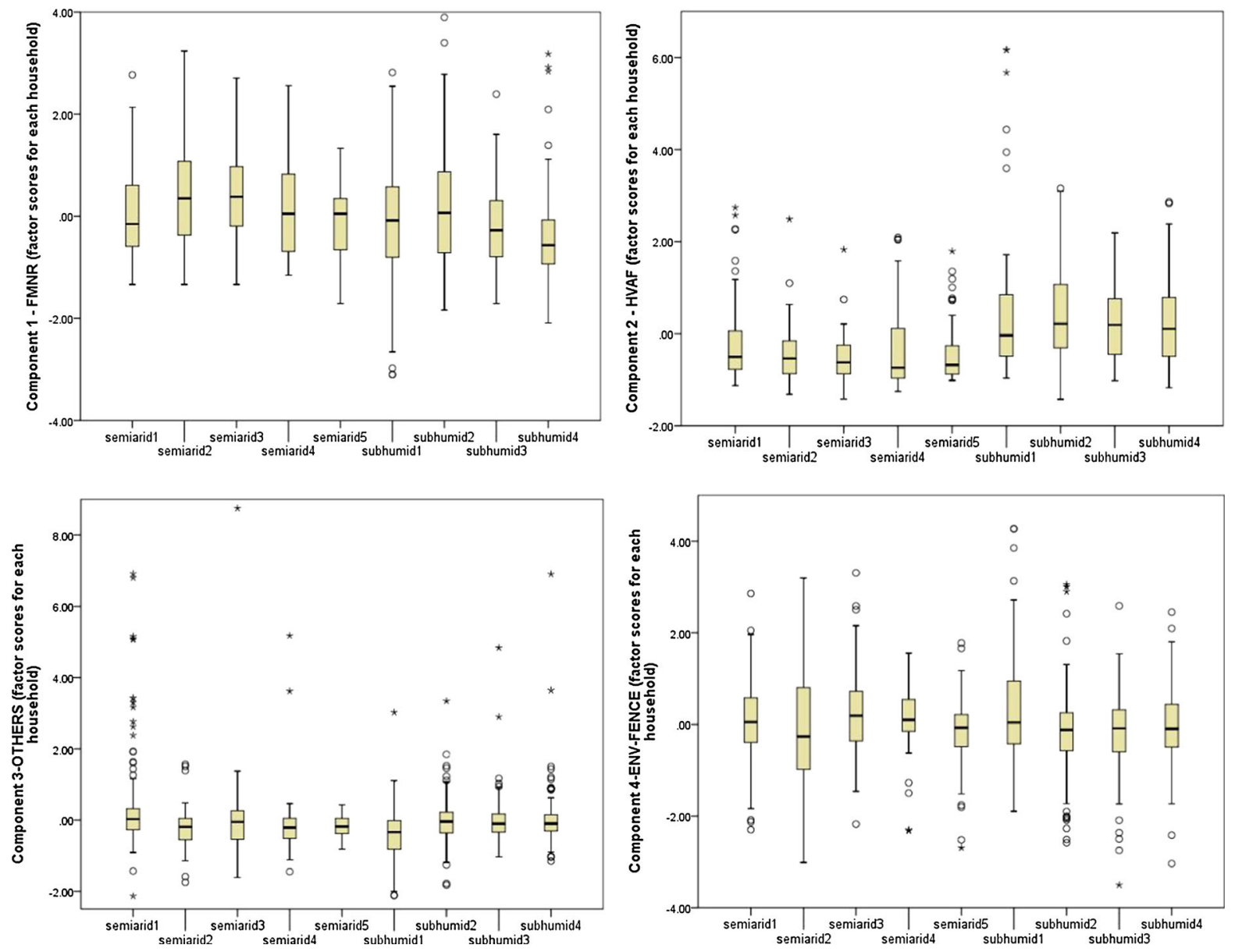

Fig. 3 Box plots of derived principal component factor scores for households by study sites

Asset/income profiles also have contrasting patterns of association with FMNR and HVAF. HVAF is associated positively with farm asset value, as well as tree-based income and regular business off-farm income while negatively associated with animal farm income, roots and tuber farm income and casual offfarm income. This implies that intensive agroforestry requires livelihood assets that can be invested in tree planting that possibly diverts livelihood strategies away from traditional livestock or low-paying casual/farming activities. In contrast FMNR has no significant associations with assets, but positive association with cereal and pulse farm income and offfarm income from rent, thus is consistent with traditional staple crop-based livelihoods.

While access to training and training centres were found positive for FMNR and HVAF, there seems room for improving extension modes for promoting agroforestry adoption, as attendance at community meetings had negative associations with both, and field days had a negative association with FMNR. It is contrary to the expectation to find that longer distances to markets, roads and services are found positive for the adoption not only for FMNR of subsistence nature but also HVAF. The significance of longer distances to market was also reported for adoption of improved wheat in Oromia (Solomon et al. 2014). They explained the unexpected outcome on the basis that farmers nearer to markets would focus on more market oriented crops than wheat whose local market was comparatively underdeveloped. In regard to our finding, though, its significant positive association with tree-based income, opportunities of HVAF may not have been fully exploited in the sub-humid sites which were in general rather isolated from market and infrastructure access during the time of the survey. A 


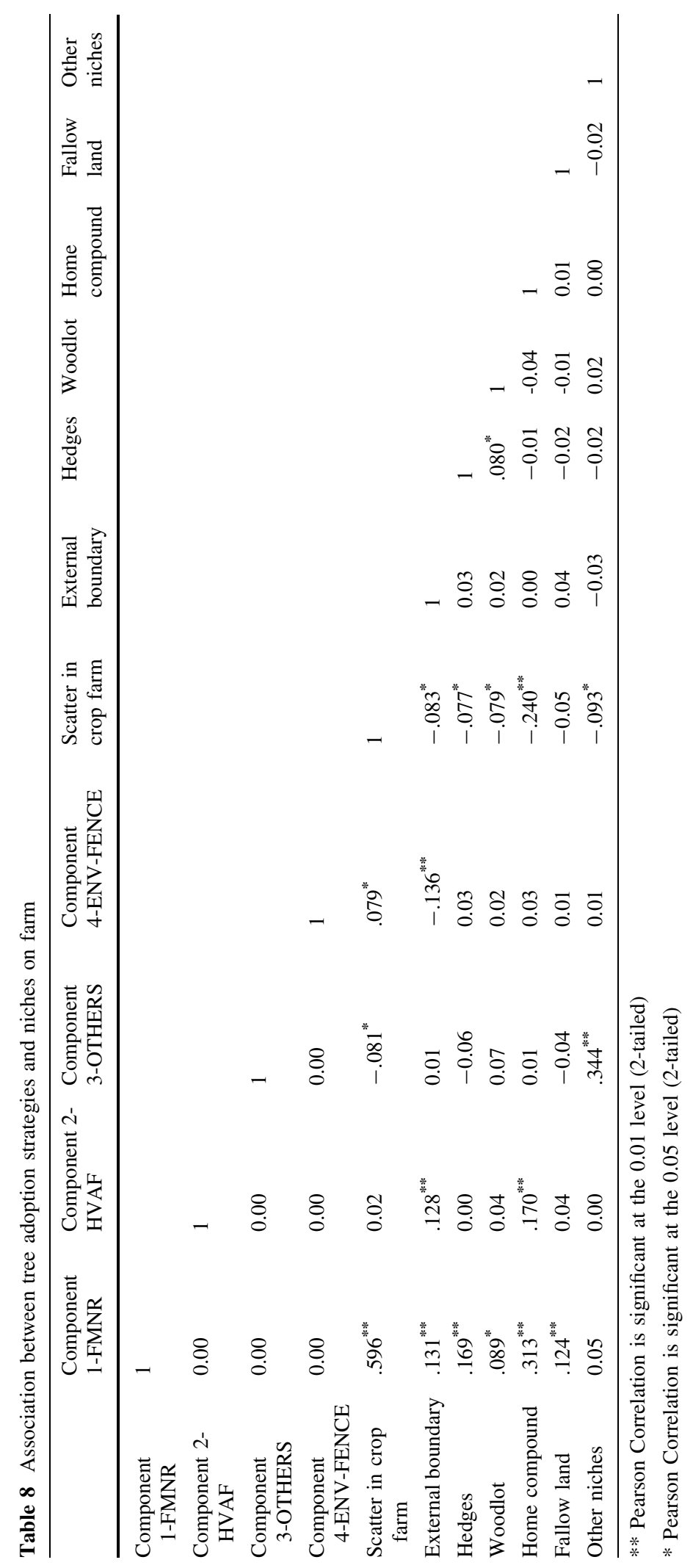


Table 9 Regression analysis of contextual factors on tree adoption strategies

\begin{tabular}{|c|c|c|c|c|}
\hline & \multicolumn{2}{|c|}{ Component 1-FMNR } & \multicolumn{2}{|c|}{ Component 2-HVAF } \\
\hline & $\mathrm{B}$ & SE & $\mathrm{B}$ & SE \\
\hline (Constant) & -.877 & $.277 * * *$ & .247 & .261 \\
\hline \multicolumn{5}{|l|}{ Biophysical factors } \\
\hline Zone dummy (semi-arid $=1$, sub-humid $=0$ ) & .432 & $.112 * * *$ & -.538 & $.106^{* * * *}$ \\
\hline Mid-highland dummy (mid-highland $=1$, otherwise $=0$ ) & .375 & $.132 * * *$ & .165 & .124 \\
\hline \multicolumn{5}{|l|}{ Preferences (demographic composition) } \\
\hline Head gender dummy $($ male $=1$, female $=0$ ) & -.187 & .170 & -.076 & .160 \\
\hline Head education level & -.045 & .072 & .044 & .068 \\
\hline Total family size & .038 & $.020 *$ & -.009 & .019 \\
\hline Male ratio & .624 & $.284 * *$ & .190 & .267 \\
\hline Working age member ratio & .421 & $.252 *$ & -.041 & .237 \\
\hline \multicolumn{5}{|l|}{ Risk and uncertainties } \\
\hline Total land size & .121 & $.052 * *$ & -.053 & .049 \\
\hline Parcel fragmentation (Simpson index) & .036 & .050 & .017 & .047 \\
\hline Mean distance of parcels from homesteads & .069 & .053 & .074 & .050 \\
\hline Proportion of parcels owned with certificate & .236 & .274 & .419 & .259 \\
\hline Proportion of parcels owned yet no certificate issued & .272 & .206 & .368 & $.194 *$ \\
\hline Proportion of parcels rented from others & .084 & .185 & .185 & .175 \\
\hline Proportion of parcels on sloped/steep land & .099 & $.049 * *$ & .018 & .046 \\
\hline Experience of free communal livestock grazing & .242 & $.048 * * *$ & -.111 & $.046 * *$ \\
\hline Experience of land resettlement & -.062 & .040 & -.056 & .038 \\
\hline Experience of tenure upgrading & .118 & $.050 * *$ & -.011 & .047 \\
\hline \multicolumn{5}{|l|}{ Resource endowments } \\
\hline Livestock-local animals & .056 & .056 & -.017 & .052 \\
\hline Livestock-exotic animals & -.075 & .050 & -.048 & .047 \\
\hline Asset-domestic asset value & -.019 & .044 & .012 & .041 \\
\hline Asset-communication asset value & -.079 & .053 & -.058 & .050 \\
\hline Asset-transport asset value & .051 & .048 & -.139 & $.045 * * *$ \\
\hline Asset-farm asset value & .000 & .060 & .361 & $.057 * * *$ \\
\hline Farm income- cereal \& pulse & .112 & $.050 * *$ & .006 & .047 \\
\hline Farm income-cash crops & -.012 & .051 & -.021 & .048 \\
\hline Farm income-roots \& tubers & .023 & .046 & -.156 & $.044 * * *$ \\
\hline Farm income-animal & .072 & .050 & -.082 & $.047 *$ \\
\hline Farm income-tree-based & .006 & .050 & .165 & $.047 * * *$ \\
\hline Off-farm income-regular business & .049 & .047 & .102 & $.044 * *$ \\
\hline Off-farm income-casual & -.055 & .050 & -.103 & $.047 * *$ \\
\hline Off-farm income-remittance \& gift & .014 & .044 & -.042 & .041 \\
\hline Off-farm income-loan & .044 & .045 & -.108 & $.042 * *$ \\
\hline Off-farm income-rent & .143 & $.047 * * *$ & .052 & .044 \\
\hline \multicolumn{5}{|l|}{ Market incentives } \\
\hline Participation in field school & .062 & .062 & .043 & .058 \\
\hline Participation in training & .126 & $.051 * *$ & -.009 & .048 \\
\hline Participation in field day & -.094 & $.053^{*}$ & .245 & $.050 * * *$ \\
\hline Participation in field visit & -.031 & .054 & .027 & .051 \\
\hline
\end{tabular}


Table 9 continued

\begin{tabular}{|c|c|c|c|c|}
\hline & \multicolumn{2}{|c|}{ Component 1-FMNR } & \multicolumn{2}{|c|}{ Component 2-HVAF } \\
\hline & $\mathrm{B}$ & SE & $\mathrm{B}$ & SE \\
\hline Participation in demonstration farm & .026 & .052 & .011 & .049 \\
\hline Participation in interaction & -.068 & .051 & -.008 & .048 \\
\hline Participation in community meetings & -.116 & $.049 * *$ & -.142 & $.046^{* * *}$ \\
\hline Participation in training centres & .121 & $.059 * *$ & .050 & .056 \\
\hline Distances to markets, roads \& services & .135 & $.046 * * *$ & .077 & $.043 *$ \\
\hline F-value & 4.135 & $.000^{\mathrm{b}}$ & 6.837 & $.000^{\mathrm{b}}$ \\
\hline Adjusted $\mathrm{R}^{2}$ & .219 & & .343 & \\
\hline
\end{tabular}

*** Significant at $1 \%$; ** significant at $5 \%$; significant at $1 \%$

plausible explanation for the negative association with proximity to markets might be that farmers nearer to markets in semi-arid sites tend to focus on cash crops such as nug and maize, whose markets are relatively well developed, rather than less well known tree crops.

Overall, the regression results indicated the significant impacts of biophysical factors as well as risk and uncertainties on FMNR and HVAF in often contrasting manners, as Pattanayak et al. (2003) also concluded from their meta-analysis that tree planting behavior is most likely to be significantly influenced by these factors. While favorable climatic conditions are a pre-requisite for HVAF, poorer biophysical potential and sloping land appear to provide a positive incentive to adopt FMNR, which has ecosystem service benefits. The possibility of tenure upgrading provides a positive incentive for FMNR by reducing the risks of land appropriation, while communal grazing is also consistent with the adoption of FMNR. In contrast, the adoption of HVAF is deterred by communal grazing which may discourage tree planting because of increased survival risks of seedlings, confirming Pattanayak et al.'s (2003) finding that the adoption of intensive tree planting is contingent on lower risk.

Pattanayak et al. (2003) found that household preference proxies were significant in only $41 \%$ of tree adoption studies related to tree planting, so they were not as critical as biophysical factors and risk and uncertainty, and that the significance and sign of preference variables were often ambiguous. Our research found that some preference variables were important in influencing adoption of FMNR but not HVAF. A probable explanation is that FMNR, which is driven more by multiple utility and locational flexibility, may be facilitated by the availability of labor as well as land. In contrast, more resource endowment variables were significant for HVAF than for FMNR. Resource endowments are likely to be positively correlated with the probability of adoption of tree planting as an investment driven by economic utility.

\section{Conclusion}

Analysis of household data revealed two distinct strategies for tree adoption in the semi-arid and humid zones of Ethiopia: farmer managed regeneration (FMNR) and planting high value tree species. We revealed that FMNR is a dominant agroforestry practice not only in the semi-arid zone but also on sloping land in the sub-humid zone, and it is consistent with supporting subsistence staple-crop production through provision of multiple utilities that can alleviate negative biophysical constraints. In contrast, high value agroforestry (HVAF) is practiced more in the sub-humid zone and associated with tree-based farm income, assets and off-farm enterprises. Biophysical conditions and resource endowments are not the only determinants of tree planting strategies. Reducing risk and uncertainty through policy and institutional arrangements is critical to ensure tenure security for people to adopt FMNR on one hand, and to handle externalities of communal grazing and adopt HVAF on the other hand. Preferences, which were represented by household demographic variables, were found more important for the adoption of FMNR as 
larger labour combined with larger land may facilitate locational flexibility. The impacts of market incentives turned out rather contradictory and ambiguous, which may indicate markets and extension systems to promote agroforestry to enhance tree-based incomes and enterprises were not yet fully functional in the study sites.

Our findings imply the critical importance of understanding farmers' preferences for specific species with multiple utilities and locational flexibility (Biggelaar and Gold 1996) which define their management intensities and niches to make fine-scale recommendations of optimal mixes of species and management options. For example, in the sub-humid zone, managing multi-purpose trees, such as Cordia africana, are widely adopted by farmers, as a dominant feature of agricultural landscapes (Yadessa et al. 2009). Interestingly, some farmers consider Cordia africana as primarily a timber species to earn income and secondarily for fencing and/or/shade and so deliberately plant the tree in homesteads or along external boundaries. Others that primarily see the species as fuelwood and also a soil amendment protect naturally regenerating trees on their farms. Either way, the tree contributes to enhancing livelihoods and food security, even though preferred management modes and intensities vary depending on farmers' perceptions and preference.

It is clear that FMNR as well as other indigenous practices deserve more attention when designing tree promotion initiatives, as they serve a critical role in alleviating negative production conditions through the provision of ecosystem services. Our findings reveal that farmers integrate many native and exotic tree species on their farms to meet their variable farm conditions, needs and asset profiles in stark contrast to most tree promotion efforts that focus on a few, usually exotic, tree species. We recommend that future agroforestry promotion should embrace a diversity of tree species appropriate to matching the fine scale variation in ecological conditions and farmer circumstances encountered in the field.

Acknowledgments This study as a part of the baseline survey of the "Trees for Food Security Project" funded by the Australian Centre for International Agricultural Research (ACIAR) and the CGIAR Research Programme on Forests, Trees and Agroforestry. We acknowledge the Ethiopian Institute of Agricultural Research (EIAR) for supporting the implementation of the data collection through mobilizing enumerators and arranging logistics during the survey. The World Agroforestry Centre's (ICRAF) Research Methodology Group (RMG) contributed greatly to the design of the survey tools, training the local enumerators and data entry.

Open Access This article is distributed under the terms of the Creative Commons Attribution 4.0 International License (http:// creativecommons.org/licenses/by/4.0/), which permits unrestricted use, distribution, and reproduction in any medium, provided you give appropriate credit to the original author(s) and the source, provide a link to the Creative Commons license, and indicate if changes were made.

\section{References}

Abeyasekera S (2001) Analysis Approaches in Participatory Work involving Ranks or Scores. A theme paper written for the DFID-funded NRSP project R7033, Statistical Services Centre, The University of Reading. http://www.reading.ac. uk/ssc/resources/AnalysisApproachesInParticipatoryWork InvolvingRanksOrScores.pdf

ARD Inc. (2004) Ethiopia Land Policy and Administration Assessment Final Report with Appendices. Submitted to USAID/Ethiopia. May 2004. USAID Contract No. LAG00-98-00031-00, Task Order No. 4

Bewket W (2002) Land cover dynamics since the 1950s in Chemoga Watershed, Blue Nile Basin, Ethiopia. Mt Res Dev 22(3):263-269

Biggelaar CD, Gold MA (1996) Development of utility and location indices for classifying agroforestry species: the case of Rwanda. Agrofor Syst 34:229-246

Bizimana C, Nieuwoudt WL, Ferrer SRD (2004) Farm size, land fragmentation and economic efficiency in southern Rwanda. Agrekon 43(2):244-262

Blarel B, Hazell P, Place F, John Quiggin J. (1992, May) The economics of farm fragmentation: evidence from Ghana and Rwanda. The World Bank Economic Review, vol 6, no. 2 (May, 1992), pp 233-254. http://www.jstor.org/ stable/3989856

Central Statistical Agency (2010) Population Size of Kebeles, Central Statistical Agency, 2010-07. http://www.csa.gov. et/newcsaweb/images/documents/surveys/Population $\% 20$ and $\% 20$ Housing $\% 20$ census/ETH-pop-2007/survey0/data/ Doc/Reports/STATISTICAL_OROMIYA/Statistical_ Oromiya_PartV.pdf

Coe R, Njoloma J, Sinclair FL (2016) Loading the dice in favour of the farmer: reducing the risk of adopting agronomic innovations. Exp Agric (in press)

Degefu T, Wolde-meskel E, Frostegård A (2011) Multilocus sequence analyses reveal several unnamed Mesorhizobium genospecies nodulating Acacia species and Sesbania sesban trees in Southern regions of Ethiopia. Syst Appl Microbiol 34:216-226. doi:10.1016/j.syapm.2010.09.006

Deininger K, Jin S (2006) Tenure security and land-related investment: evidence from Ethiopia. Eur Econ Rev 50(2006):1245-1277. doi:10.1016/j.euroecorev.2005.02.001

Deininger K, Ali DA, Holden S, Zebenbagen J (2008) Rural land certification in Ethiopia: process, Initial impact, and 
implications for other African countries. World Dev 36(10):1786-1812. doi:10.1016/j.worlddev.2007.09.012

Deininger K, Ayalew D Ali, Alemu T (2009) Impacts of land certification on tenure security, investment, and land markets evidence from Ethiopia. Environment for Development. Discussion Paper Series April 2009. EfD DP 09-11

Deressa TT, Hassan RM, Ringler C, Alemu T, Yesuf M (2009) Determinants of farmers' choice of adaptation methods to climate change in the Nile Basin of Ethiopia. Glob Environ Change 19(2009):248-255. doi:10.1016/j.gloenvcha.2009. 01.002

Duguma LA (2013) Financial analysis of agroforestry land uses and its implications for smallholder farmers livelihood improvement in Ethiopia. Agrofor Syst 87:217-231. doi:10.1007/s 10457-012-9537-.1

Endale Y (2014) Assessment of tree species, diversity distribution patterns and socioeconomic uses on farmland in Oromia Regional State: The case of East Shewa Zone. A thesis submitted to the center for environmental science, presented in partial fulfilment of the requirements for the degree of master of environmental science, Addis Ababa university, Addis Ababa, Ethiopia

Ethiopian Government Portal. The Oromia National Regional State http://www.ethiopia.gov.et/stateoromia. Accessed 17 Jan 2016

FAO (2012) FRA 2015 Terms and definition, forest resources assessment working Paper 180. Food and Agriculture Organization of the United Nations, Rome

Federal Democratic Republic of Ethiopia Population Census Commission. (2008) Summary and Statistical Report of the 2007 Population and Housing Census. United Nations Population Fund(UNFPA), Addis Ababa. http://ecastats. uneca.org/aicmd/Portals/0/Cen2007_firstdraft.pdf

Franzel S, Scherr SJ (2002) Trees on the farm: assessing the adoption potential of agroforestry practices in Africa. CAB International, Published in association with ICRAF, Nairobi

Gebremedhin B, Pender J, Tesfay G (2004) Collective action for grazing land management in crop-livestock mixed systems in the highlands of northern Ethiopia. Agric Syst 82(2004):273-290. doi:10.1016/j.agsy.2004.07.004

Gelaw AM, Singh BR, Lal R (2014) Soil organic carbon and total nitrogen stocks under different land uses in a semiarid watershed in Tigray, Northern Ethiopia. Agric Ecosyst Environ 188(2014):256-263. doi:10.1016/j.agee.2014.02. 035

Holden ST, Deininger K, Ghebru H (2011) Tenure insecurity, gender, low-cost land certification and land rental market participation in Ethiopia. J Dev Stud 47(1):31-47. doi:10. 1080/00220381003706460

Hylander K, Nemomissa S (2008) Complementary roles of home gardens and exotic tree plantations as alternative habitats for plants of the Ethiopian Montane Rainforest. Conserv Biol 23(2):400-409. doi:10.1111/j.1523-1739. 2008.01097.x

Iiyama M, Kariuki P, Kristjanson P, Kaitibie S, Maitima J (2008) Livelihood diversification strategies, incomes and soil management strategies: a case study from Kerio Valley, Kenya. J Int Dev 20:380-397. doi:10.1002/jid.1419

Israel GD (1992) Sampling the Evidence of Extension Program Impact. Program Evaluation and Organizational Development, IFAS, University of Florida. PEOD-5.October
Jagger P, Pender J (2003) The role of trees for sustainable management of less-favored lands: the case of eucalyptus in Ethiopia. For Policy Econ 5:83-95

Jagger P, Pender J, Gebremedhin B (2005) Trading off environmental sustainability for empowerment and income: Woodlot devolution in Northern Ethiopia. World Dev 33(9):1491-1510. doi:10.1016/j.worlddev.2004.10.010

Kassahun A, Snyman HA, Smit GN (2009) Soil seed bank evaluation along a degradation gradient in arid rangelands of the Somali region, eastern Ethiopia. Agric Ecosyst Environ 129:428-436. doi:10.1016/j.agee.2008.10.016

Linger E (2014) Agro-ecosystem and socio-economic role of home garden agroforestry in Jabithenan District, NorthWestern Ethiopia: implication for climate change adaptation. Linger Springer Plus 2014, 3:154. http://www. springerplus.com/content/3/1/154

Meijer SS, Catacutan D, Ajayi OC, Gudeta W, Sileshi GW, Nieuwenhuis M (2015) The role of knowledge, attitudes and perceptions in the uptake of agricultural and agroforestry innovations among smallholder farmers in subSaharan Africa. Int J Agric Sustain 13(1):40-54. doi:10. 1080/14735903.2014.912493

Mekuria W, Aynekulu E (2013) Exclosure land management restores soil properties of degraded communal grazing lands in northern Ethiopia. Land Degrad Dev 24:528-538

Mercer DE (2004) Adoption of agroforestry innovations in the tropics: a review. Agrofor Syst 61(1):311-328

Negash M (2007) Trees Management and Livelihoods in Gedeo's Agroforests, Ethiopia. For Trees Livelihoods 17:157-168

Nyaga J, Barrios E, Muthuri CW, Öborn I, Matiru V, Sinclair FL (2015) Evaluating factors influencing heterogeneity in agroforestry adoption and practices within smallholder farms in Rift Valley, Kenya. Agric Ecosyst Environ 212:106-118

Pattanayak SK, Mercer DE, Sills E, Yang JC (2003) Taking stock of agroforestry adoption studies. Agrofor Syst 57:173-186

Place F (2009) Land tenure and agricultural productivity in Africa: a comparative analysis of the economics literature and recent policy strategies and reforms. World Dev 37(8):1326-1336. doi:10.1016/j.worlddev.2008.08.020

Poschen P (1986) An evaluation of the Acacia albida-based agroforestry practices in the Hararghe highlands of Eastern Ethiopia. Agrofor Syst 4:129-143

Sinclair FL (1999) A general classification of agroforestry practice. Agrofor Syst 46:161-180

Sinclair FL, Walker DH (1999) A utilitarian approach to the incorporation of local knowledge in agroforestry research and extension. In: Buck LE, Lassoie JP, Fernandes ECM (eds) Agroforestry in sustainable agricultural systems. Lewis Publishers, New York, pp 245-275

Solomon T, Tessema A, Bekele A (2014) Adoption of improved wheat varieties in Robe and DigeluTijo Districts of Arsi Zone in Oromia Region, Ethiopia: a double-hurdle approach. Afr J Agric Res 9(51):3692-3703. doi:10.5897/ AJAR2014.9047

Teklay T, Nordgren A, Nyberg G, Malmer A (2007) Carbon mineralization of leaves from four Ethiopian agroforestry species under laboratory and field conditions. Appl Soil Ecol 35(2007):193-202. doi:10.1016/j.apsoil.2006.04.002 
Tesfaye A, Negatu W, Brouwer R, Van der Zaag P (2014) Understanding soil conservation decisions of farmers in the Gedeb Watershed, Ethiopia. Land Degrad Dev 25:71-79. doi:10.1002/ldr.2187

Teshome DS. (2014) Assessment of tree species, diversity distribution patterns and socioeconomic uses on agricultural landscapes: A case of Western Oromia, Ethiopia. M.Sc. Thesis submitted to the Graduate Studies Jimma University College of Agriculture and Veterinary Medicine, in partial fulfillment of the requirements for the degree of Master of Science in Natural Resource Management (Forest and Nature Conservation). Jimma University, Jimma, Ethiopia The National Regional Government of Oromia, Regional Statistical Abstract, Physical \& Socio-Economic Profile and Economic Account Statistics, Physical and Socio-Economic Profile Of Oromia, http://www.oromiabofed.org/
images/stories/rstatistics/Physical_and_Socio_Economic_ Profile_Of_Oromia.zip. Accessed 7 Jan 2016

The University of Reading Statistical Services Centre. (2001) Approaches to the Analysis of Survey Data, Biometrics Advisory and Support Service to DFID, Statistical Services Centre, The University of Reading, UK. http://www. reading.ac.uk/ssc/resources/ApproachesToTheAnalysisOf SurveyData.pdf

Tiffen M, Mortimore M, Gichuki F (1994) More people, less erosion. Environmental recovery in Kenya. ACTS Press, Nairobi

Yadessa A, Itanna F, Olsson M (2009) Scattered trees as modifiers of agricultural landscapes: the role of waddeessa (Cordia africana Lam.) trees in Bako area, Oromia. Ethiopia. Afr J Ecol 47(Suppl. 1):78-83 